\title{
Reproduction of Ooencyrtus submetallicus (Hymenoptera: Encyrtidae) and Trissolcus sp. aff. urichi (Hymenoptera: Scelionidae) in Eggs of Nezara viridula (Hemiptera: Pentatomidae) of Different Ages
}

\author{
Eduardo Carvalho Faca ${ }^{1}$, Fabrício Fagundes Pereira ${ }^{1}$, Winnie Cezario Fernandes ${ }^{1}$, Ivana Fernandes da Silva ${ }^{1}$, \\ Valmir Antônio Costa ${ }^{2} \&$ Ana Paula Gonçalves da Silva Wengrat ${ }^{3}$ \\ ${ }^{1}$ Programa de Pós-graduação de Entomologia e Conservação da Biodiversidade, Universidade Federal da Grande \\ Dourados (UFGD), Dourados, Mato Grosso do Sul, Brazil \\ ${ }^{2}$ Instituto Biológico, Agência Paulista de Tecnologia dos Agronegócios, Secretaria de Agricultura e \\ Abastecimento, Campinas, São Paulo, Brazil \\ ${ }^{3}$ Departamento de Entomologia e Acarologia, Universidade de São Paulo (USP)/Escola Superior de Agricultura \\ "Luiz de Queiroz" (ESALQ), Piracicaba, São Paulo, Brazil \\ Correspondence: Eduardo Carvalho Faca, Programa de Pós-graduação em Entomologia e Conservação da \\ Biodiversidade, Universidade Federal da Grande Dourados, Dourados, Mato Grosso do Sul, Brazil. Tel: \\ 55-679-8171-6491. E-mail: eduardofaca@gmail.com
}

Received: July 23, 2021

doi:10.5539/jas.v13n10p96
Accepted: August 20, 2021

Online Published: September 15, 2021

URL: https://doi.org/10.5539/jas.v13n10p96

\begin{abstract}
The study of the interaction between parasitoid and host, especially the age of these organisms, is an important step towards the implementation of biological control programs. Therefore, we investigated the performance of Ooencyrtus submetallicus (Hymenoptera: Encyrtidae) and Trissolcus sp. aff. urichi (Hymenoptera: Scelionidae) parasitizing eggs of Nezara viridula (Hemiptera: Pentatomidae), considering different ages of the parasitoids and the host. We performed four laboratory bioassays: two using females of $O$. submetallicus and Trissolcus sp. aff. urichi at $24,48,72,96,120$, or 144 hours of age exposed to parasitism in $N$. viridula eggs $(24 \mathrm{~h})$ and two trials with $N$. viridula eggs at 24, 48,72,96, 120, or 144 hours exposed to the parasitism of $O$. submetallicus and Trissolcus sp. aff. urichi $(24 \mathrm{~h})$. We evaluated the percentage of parasitism and emergence, life cycle length, progeny, sex ratio, and the longevity of the parasitoids. The parasitism of $O$. submetallicus in $N$. viridula eggs was influenced by the age of the parasitoid, 120 hours being the minimum to obtain better parasitism. From this age on, there is interference in the longevity of the progeny. Trisolcus sp. aff. urichi, at all ages, parasitized N. viridula eggs relatively well, but with almost no emergence of the parasitized eggs. Females of $O$. submetallicus parasitized and developed in eggs of $N$. viridula of all ages. Females of Trissolcus sp. aff. urichi parasitized their host, but there was barely any emergence. These pieces of information regarding the breeding methodology contribute to the implementation of new protocols for the multiplication of these parasitoids in the laboratory, and later, their release in the field.
\end{abstract}

Keywords: biological control, host-parasitoid interaction, breeding methodology, egg parasitoid, green stink bug

\section{Introduction}

Biological control is an environmentally friendly and affordable management alternative, adopted to reduce insect populations considered pests for their natural enemies (Parra et al., 2002). In addition, this type of control is used to minimize excessive applications of synthetic insecticides, being a viable tool when associated with other strategies adopted by Integrated Pest Management (IPM) (Parra, 2014; Van Lenteren et al., 2018).

For the success of a biological control program, studies involving the interaction between the natural enemy and its host are needed, in order to understand the biology of these organisms and then adopt them as biological control agents (Parra \& Zucchi, 2004; Siqueira et al., 2012). Several egg parasitoids have been reported, studied, and used as biological control agents (Crouzel \& Saini, 1981; Corrêa-Ferreira \& Moscardi, 1996; Queiroz et al., 2018; Martel et al., 2019; Stahl et al., 2019; Zerbino \& Panizzi, 2019; Scaccini et al., 2020). 
Among these, the parasitoids Ooenycyrtus submetallicus (Howard) (Hymenoptera: Encyrtidae) and Trissolcus urichi (Crawford) (Hymenoptera: Scelinidae) parasitize eggs of several species of stink bugs (Zanuncio et al., 2000; Maciel et al., 2007; Laumann et al., 2010; Riffel et al., 2010; Golin et al., 2011; Sousa et al., 2019). Like those of Nezara viridula (L.) (Hemiptera: Pentatomidae), known as the green bug (Lee, 1979; Sujii et al., 2002; Paz-Neto et al., 2015; Zerbino \& Panizzi, 2019).

The green stink bug and other species of the complex group of phytophagous of the Pentatomidae family cause irreversible damage to the soybean crops from the beginning of pod formation to the final grain filling stage, affecting both yield and final quality (Panizzi \& Slansky Jr, 1985; Soares et al., 2018). Commonly, species of the Pentatomidae complex are controlled with synthetic insecticides, both in seed treatment and in aerial application at the initial stages of crop development (Chiesa et al., 2016). However, this management method has been associated with the emergence of insect populations resistant to the main groups of insecticides adopted, the reduction of natural control agents, as well as other implications for the agroecosystem (Sosa-Gómez et al., 2001; Sosa-Gómez et al., 2010, Turchen et al., 2016).

Therefore, having knowledge and development of research involving the interaction between the parasitoid and the host is necessary to increase the efficiency and success of biological control programs (Parra \& Zucchi, 2004; Parra et al., 2019). Among these interactions, studying the age of both parasitoid and host females is not only important for analyzing the performance of biological control agents but also for predicting their establishment in the field (Cingolani et al., 2014; Queiroz et al., 2019; Hill et al., 2019; Queiroz et al., 2020a). Considering this, we determined the age of the parasitoids $O$. submetallicus and Trissolcus sp. aff. urichi that are considered optimal for parasitism in eggs of $N$. viridula. Furthermore, we evaluated the influence of the host egg age on the multiplication of both parasitoids and the influence of these factors on their biological characteristics.

\section{Method}

\subsection{Laboratory Breeding of O. submetallicus, Trissolcus sp. aff. urichi and N. viridula}

The experiments were set up based on stock cultures of the parasitoids $O$. submetallicus and Trissolcus sp. aff. urichi and host $N$. viridula, kept in an acclimatized room with temperature of $25 \pm 2{ }^{\circ} \mathrm{C}$, relative humidity of $70 \pm 10 \%$ RH, and a 12-hour photophase. The parasitoids $O$. submetallicus and Trissolcus sp. aff. urichi were identified according to Noyes (2010) and Johnson (1987), respectively. Voucher specimens were deposited at Coleção de Insetos Entomófagos "Oscar Monte" (Instituto Biológico, Campinas, SP, Brazil; curator Valmir A. Costa).

Nymphs and adults of $N$. viridula were placed in a $5 \mathrm{~L}$ transparent plastic containers and fed with fresh pods of Phaseolus vulgaris (Fabaceae), seeds of Ligustrum sp. (Oleaceae), raw grains of Arachis hypogaea L. (Fabaceae), and dry grains of Glycine max (Fabaceae) (Silva et al., 2008). In addition to portions of cotton moistened in distilled water to supply the insect's water needs. Filter paper $(30 \mathrm{~cm} \times 30 \mathrm{~cm})$ folded in a fan shape and voile fabric $(30 \mathrm{~cm} \times 30 \mathrm{~cm})$ were placed as a substrate for the stink bugs' oviposition. Adults of $O$. submetallicus and Trissolcus sp. aff. urichi were kept in glass tubes $(15 \mathrm{~cm}$ high $\times 2 \mathrm{~cm}$ in diameter) closed with plastic film, fed with a droplet of honey (100\%), and then multiplied into egg masses of $N$. viridula and Chinavia pengue (Rolston) (Hemiptera: Pentatomidae), respectively. The identification of the species $N$. viridula and C. pengue was carried out by Dr. Jocélia Grazia, (Universidade Federal do Rio Grande do Sul) Porto Alegre, Rio Grande do Sul.

\subsection{Experimental Development}

\subsubsection{Age of $O$. submetallicus and Trissolcus sp. aff. urichi Reared in Eggs of $N$. viridula}

Five eggs of the host $N$. viridula (yellow and not deformed, 24 hours of age) were offered to each female of $O$. submetallicus at $24,48,72,96,120$, or 144 hours of age, as well as to each female of $O$. submetallicus at $24,48,72$, 96, 120, or 144 hours of age. Trisolcus sp. aff. urichi, and they were kept separately. These eggs were placed on cardboard cartons $(1 \times 5 \mathrm{~cm})$, fixed with $20 \%$ gum arabic, and inserted into glass tubes $(2 \mathrm{~cm}$ in diameter $\times 15 \mathrm{~cm}$ in height) (Figure 1A). After 24 hours of parasitism, the females of the parasitoids were removed from the tubes and the hosts were transferred to the climatized chamber (BOD) at $25 \pm 2{ }^{\circ} \mathrm{C}, 70 \pm 10 \%$ relative humidity, and 12-hour photophase until the emergence of the parasitoid adults.

\subsubsection{Age of N. viridula Eggs Offered to the Parasitoids O. submetallicus and Trissolcus sp. aff. urichi}

Five eggs of the host $N$. viridula (yellow and not deformed) at 24, 48, 72, 96, 120, or 144 hours of age were placed on cardboard sheets $(1 \times 5 \mathrm{~cm})$, fixed with $20 \%$ gum arabic, and inserted in glass tubes $(2 \mathrm{~cm}$ in diameter $\times 15 \mathrm{~cm}$ in height). Later, they were offered to females of $O$. submetallicus and Trissolcus sp. aff. urichi, both at 24 hours of age, in separate tubes (Figure 1B). After 24 hours of parasitism, the females of each species were removed from the tubes and the cardboards containing the host's eggs were transferred to a climatized chamber (BOD) at $25 \pm 2{ }^{\circ} \mathrm{C}$, $70 \pm 10 \%$ relative humidity, and a 12 -hour photophase until possible emergence of adults of the parasitoids. 
(A)

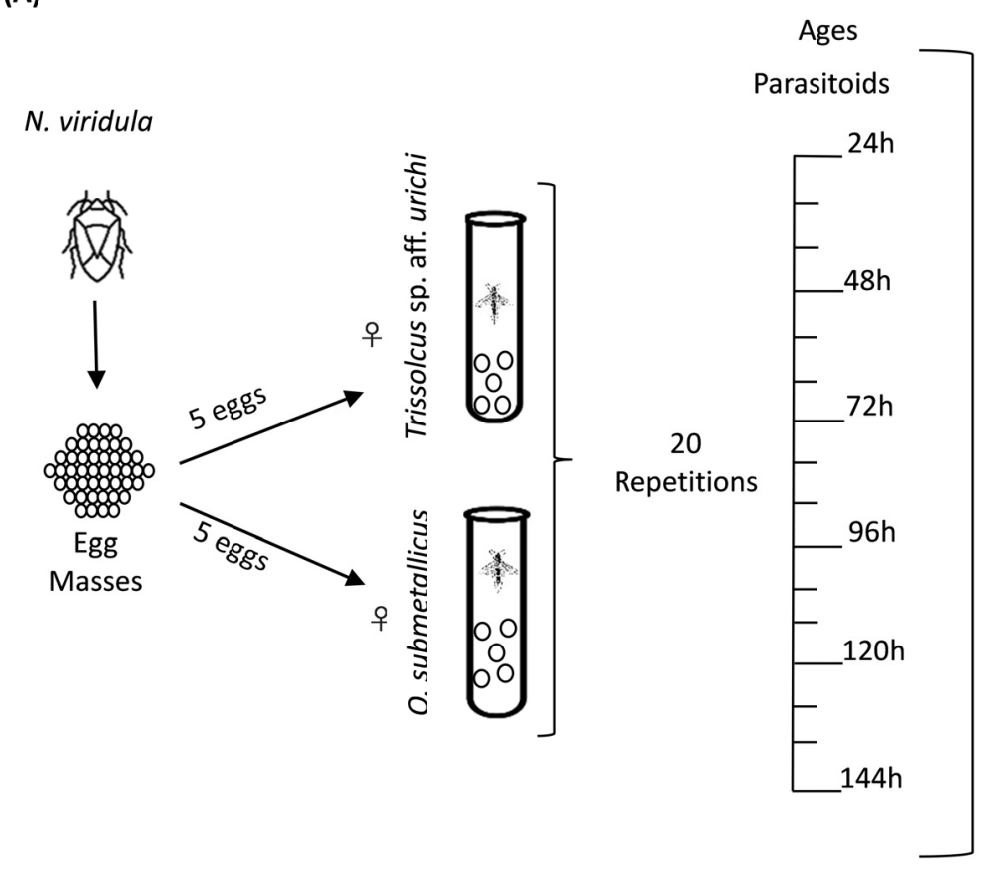

(B)

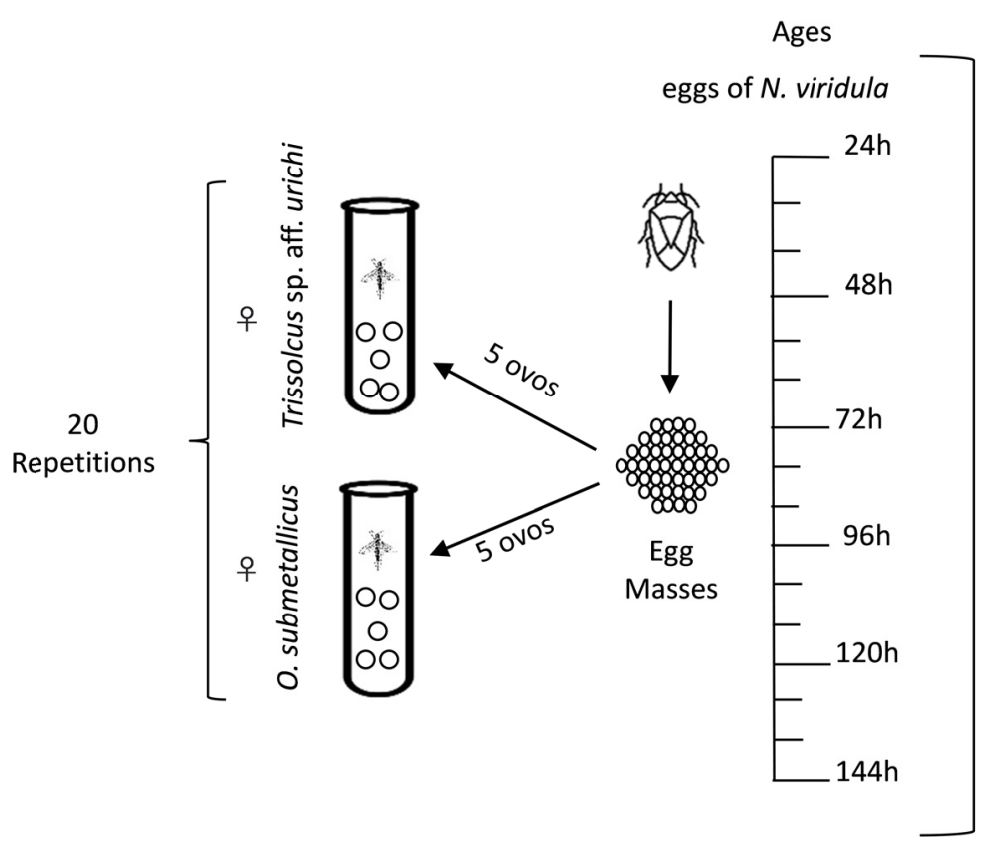

Figure 1. Scheme of experimental development. (A) ages of females of the parasitoids Ooencyrtus submetallicus (Hymenoptera: Encyrtidae) and Trissolcus sp. aff. urichi (Hymenoptera: Scelionidae) at 24, 48, 72, 96, 120, or 144 hours exposed to parasitism in eggs of the host Nezara viridula (Hemiptera: Pentatomidae) $(n=5)$. (B) ages

of $N$. viridula host eggs $(\mathrm{n}=5)$ at $24,48,72,96,120$, or 144 hours exposed to parasitism of females of $O$. submetallicus and Trissolcus sp. aff. urichi. Kept at $25 \pm 2{ }^{\circ} \mathrm{C}, 70 \pm 10 \%$ relative humidity, and 12-hour photophase.

Dourados, Mato Grosso do Sul, Brazil

\subsection{Experimental Evaluation}

The biological characteristics evaluated were: percentage of parasitism and parasitoid emergence; life cycle length (egg-adult); progeny (number of individuals per egg); adult longevity (with food) and sex ratio (number of females/total number of individuals). The experimental design used was completely randomized, with 20 
repetitions per treatment (age of parasitoids and age of host eggs). Data on life cycle length, percentage of parasitism and parasitoid emergence, number of individuals per egg, sex ratio, and longevity were submitted to analysis of variance, and, when significant, of regression with 5\% probability (Software Sigmaplot 12.0).

The choice of the best suitable equation was based on the Coefficient of Determination $\left(\mathrm{R}^{2}\right)$, the significance of the Regression Coefficients $\left({ }^{\beta} \mathrm{i}\right.$ ), and the Regression by Test $\mathrm{F}$ (at $5 \%$ probability).

\section{Results}

\subsection{Age of O. submetallicus and Trissolcus sp. aff. urichi in eggs of N. virirula}

Parasitism progressively increased with the age of females of $O$. submetallicus in $N$. viridula eggs, going from $40.00 \pm 20.00 \%$ at 24 hours to $97.33 \pm 1.82 \%$ at 144 hours $(F=41.2610, p \leq 0.0001$ and $R$ trat $=0.83$ ) (Figure 2$)$. The emergence percentage of $O$. submetallicus in $N$. viridula eggs was not a significant factor when related to the ages of this parasitoid, although it remained high during the six days $(144 \mathrm{~h})$, presenting an overall average of $94.52 \pm 1.61 \%(\mathrm{p}>0.05)$ (Table 1$)$.

The length of the life cycle (egg-adult), progeny, and sex ratio of $O$. submetallicus was also not influenced by the different ages of the parasitoid ( $p>0.05$ ), presenting overall average values of $17.85 \pm 0.07$ days; $1.39 \pm 0.07$ individuals per egg and $1.00 \pm 0.00$, respectively (Table 1).

Similar to parasitism, the progeny longevity was influenced by the different ages of $O$. submetallicus females in $N$. viridula eggs $(F=10.4012, p \leq 0.0001$ and Rtrat $=0.82)$ (Figure 3$)$. Longevity decreased as parasitoid age increased, from $18.13 \pm 1.72$ days (with females aged 24 hours) to $8.50 \pm 0.44$ days (with females aged 144 hours) (Table 1).

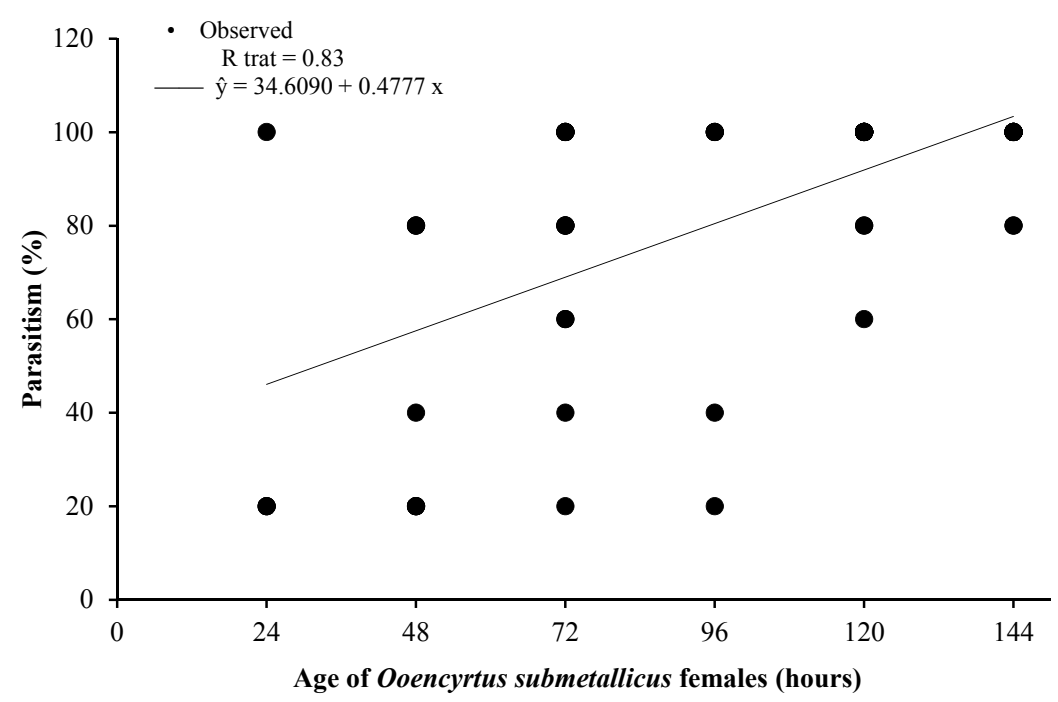

Figure 2. Parasitism (\%) of females of Ooencyrtus submetallicus (Hymenoptera: Encyrtidae) at 24, 48, 72, 96, 120, and 144 hours in eggs of Nezara viridula (Hemiptera: Pentatomidae) at $25 \pm 2{ }^{\circ} \mathrm{C}, 70 \pm 10 \%$ relative humidity and 12-hour photophase $(\mathrm{F}=41.2610$ and $\mathrm{p} \leq 0.0001)$. Dourados, Mato Grosso do Sul, Brazil

Table 1. Biological characteristics (mean $\pm \mathrm{SE}$ ) of Ooencyrtus submetallicus (Hymenoptera: Encyrtidae) at 24, 48, 72, 96, 120, and 144 hours of age, emerged from eggs of Nezara viridula (Hemiptera: Pentatomidae), under laboratory conditions at $25 \pm 2{ }^{\circ} \mathrm{C}, 70 \pm 10 \%(\mathrm{RH})$ and 12 -hour photophase. Dourados, Mato Grosso do Sul, Brazil

\begin{tabular}{lllllllll}
\hline \multirow{2}{*}{ Biological characteristics } & \multicolumn{4}{c}{ Age of the parasitoid Ooencyrtus submetallicus (hours) } & \multirow{2}{*}{ Overall average } \\
\cline { 2 - 6 } & $24 \mathrm{~h}$ & $48 \mathrm{~h}$ & $72 \mathrm{~h}$ & $96 \mathrm{~h}$ & $120 \mathrm{~h}$ & $144 \mathrm{~h}$ & & \\
\hline Emergency (\%) & $100.00 \pm 1.00$ & $89.29 \pm 4.40$ & $94.00 \pm 3.63$ & $91.00 \pm 6.06$ & $96.84 \pm 3.16$ & $96.00 \pm 2.14$ & n.s. & $95.00 \pm 1.61$ \\
Life cycle $^{1}$ (days) & $18.00 \pm 0.00$ & $17.69 \pm 0.11$ & $17.84 \pm 0.10$ & $17.59 \pm 0.19$ & $18.04 \pm 0.17$ & $17.93 \pm 0.15$ & n.s. & $17.85 \pm 0.07$ \\
Progeny $^{2}$ & $1.60 \pm 0.00$ & $1.39 \pm 0.17$ & $1.22 \pm 0.08$ & $1.22 \pm 0.10$ & $1.59 \pm 0.15$ & $1.34 \pm 0.11$ & n.s. & $1.39 \pm 0.07$ \\
Sex ratio $^{3}$ & $1.00 \pm 0.00$ & $1.00 \pm 0.00$ & $1.00 \pm 0.00$ & $1.00 \pm 0.00$ & $1.00 \pm 0.00$ & $1.00 \pm 0.00$ & n.s. & $1.00 \pm 0.00$ \\
\hline
\end{tabular}

Note. n.s. $=$ not significant $(\mathrm{p}>0.05) ;{ }^{1}$ total egg duration-adult $;{ }^{2}$ number of individuals per egg; ${ }^{3} \mathrm{n}^{\circ}$ of females $/\left(\mathrm{n}^{\circ}\right.$ of males $+n^{\circ}$ of females). 


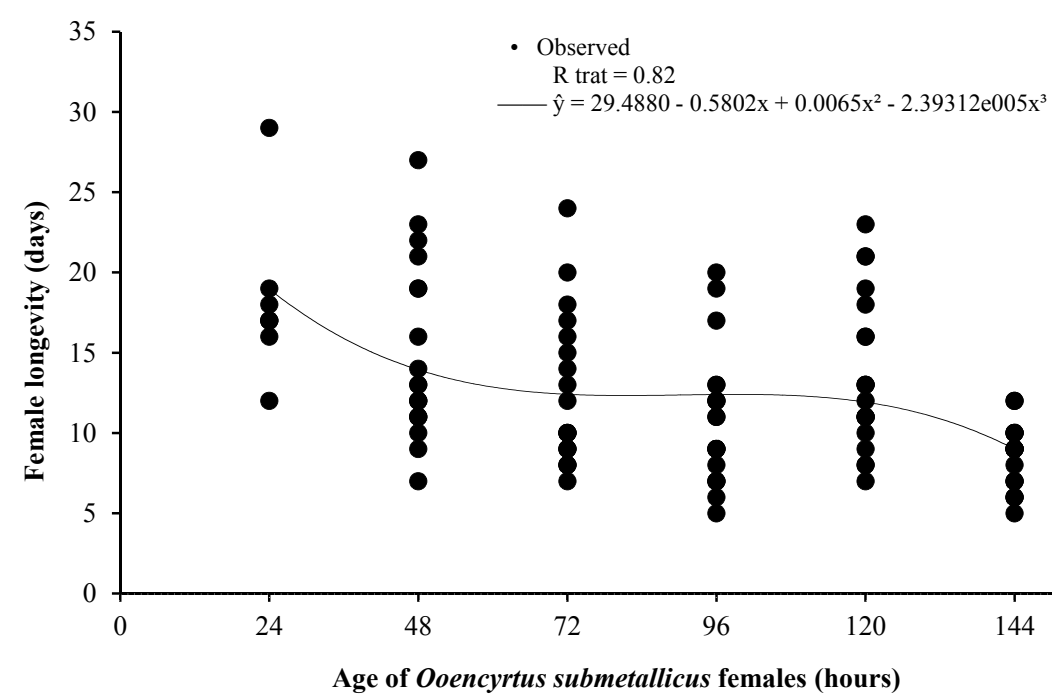

Figure 3. Longevity (days) of Ooencyrtus submetallicus (Hymenoptera: Encyrtidae) aged 24, 48, 72, 96, 120, and 144 hours emerged from eggs of Nezara viridula (Hemiptera: Pentatomidae) at $25 \pm 2{ }^{\circ} \mathrm{C}, 70 \pm 10 \%$ relative humidity and 12-hour photophase $(\mathrm{F}=10.4012$ and $\mathrm{p} \leq 0.0001)$. Dourados, Mato Grosso do Sul, Brazil

The different ages of Trissolcus sp. aff. urichi in $N$. viridula eggs did not influence the biological characteristics of this parasitoid $(\mathrm{p}>0.05)$. Nevertheless, a parasitism percentage higher than $75 \%$ was observed at all ages of females of Trissolcus sp. aff. urichi $(24$ to $144 \mathrm{~h})$. However, the percentage of emergence was absolutely low, presenting an overall average of $3.32 \pm 0.71 \%$, as only three individuals emerged in these treatments (24 to $144 \mathrm{~h})$ (Table 2). The average life cycle length (24 to $144 \mathrm{~h}$ ) (egg to adult) of Trissolcus sp. aff. urichi was $15.00 \pm 1.53$ days with $1.00 \pm 0.00$ progeny emerged per egg of $N$. viridula and the sex ratio was $1.00 \pm 0.00$. Although this parasitoid presents sexual reproduction and generate both males and females, only female individuals emerged from $N$. viridula eggs in our results, with overall average longevity of $2.33 \pm 1.33$ days (Table 2 ).

Table 2. Biological characteristics (mean \pm SE) of Trissolcus sp. aff. urichi (Hymenoptera: Scelionidae) at 24, 48, $72,96,120$, and 144 hours of age, emerged from eggs of Nezara viridula (Hemiptera: Pentatomidae), at $25 \pm 2{ }^{\circ} \mathrm{C}$, $70 \pm 10 \%$ of (RH) and photophase of 12 hours. Dourados, Mato Grosso do Sul, Brazil

\begin{tabular}{|c|c|c|c|c|c|c|c|c|}
\hline \multirow{2}{*}{ Biological characteristics } & \multicolumn{6}{|c|}{ Age of the parasitoid Trissolcus sp. aff. urichi (hours) } & & \multirow{2}{*}{ Overall average } \\
\hline & $24 \mathrm{~h}$ & $48 \mathrm{~h}$ & $72 \mathrm{~h}$ & $96 \mathrm{~h}$ & $120 \mathrm{~h}$ & $144 \mathrm{~h}$ & & \\
\hline Parasitism (\%) & $75.00 \pm 12.25$ & $98.33 \pm 1.67$ & $90.91 \pm 5.63$ & $93.75 \pm 5.07$ & $88.33 \pm 6.72$ & $97.78 \pm 2.22$ & n.s. & $90.68^{ \pm} 3.51$ \\
\hline Emergency (\%) & $3.33 \pm 3.33$ & - & $4.55 \pm 4.55$ & - & $2.08 \pm 2.08$ & - & n.s. & $3.32^{ \pm} 0.71$ \\
\hline Life cycle ${ }^{1}$ (days) & $14.00 \pm 0.00$ & - & $13.00 \pm 0.00$ & - & $18.00 \pm 0.00$ & - & n.s. & $15.00 \pm 1.53$ \\
\hline Progeny ${ }^{2}$ & $1.00 \pm 0.00$ & - & $1.00 \pm 0.00$ & - & $1.00 \pm 0.00$ & - & n.s. & $1.00 \pm 0.00$ \\
\hline sex ratio ${ }^{3}$ & $1.00 \pm 0.00$ & - & $1.00 \pm 0.00$ & - & $1.00 \pm 0.00$ & - & n.s. & $1.00 \pm 0.00$ \\
\hline Longevity + (days) & $5.00 \pm 0.00$ & - & $1.00 \pm 0.00$ & - & $1.00 \pm 0.00$ & - & n.s. & $2.33 \pm 1.33$ \\
\hline
\end{tabular}

Note. n.s. $=$ not significant $(\mathrm{p}>0.05) ;{ }^{1}$ total egg duration-adult; ${ }^{2}$ number of individuals per egg $;{ }^{3} \mathrm{n}^{\circ}$ of females $/\left(\mathrm{n}^{\circ}\right.$ of males $+\mathrm{n}^{\circ}$ of females).

The parasitism and the emergence of $O$. submetallicus did not vary with the age of the eggs of the host $N$. viridula $(24,48,72,96,120$, or $144 \mathrm{~h})$, with an overall average of $63.26 \pm 7.92 \%$ and $9.91 \pm 1.69 \%$, respectively $(\mathrm{p}>0.05)$. The average length of the life cycle of $O$. submetallicus was also not influenced by the ages of the host, with an overall average of $18.81 \pm 0.25$ days and with a number of individuals per egg of $1.79 \pm 0.12(\mathrm{p}>0.05)$. The sex ratio of $O$. submetallicus was $1.00 \pm 0.00$, not being a factor influenced by the different ages evaluated, as well as the longevity of adult females, which had an overall average of $13.43 \pm 0.79$ days $(p>0.05)$ (Table 3$)$. 
Table 3. Biological characteristics (mean $\pm \mathrm{SE}$ ) of Ooencyrtus submetallicus (Hymenoptera: Encyrtidae) emerged from eggs of Nezara viridula (Hemiptera: Pentatomidae) at 24, 48, 72, 96, 120, and 144 hours of age, at $25 \pm 2{ }^{\circ} \mathrm{C}, 70 \pm 10 \%(\mathrm{RH})$ and 12-hour photophase. Dourados, Mato Grosso do Sul, Brazil

\begin{tabular}{|c|c|c|c|c|c|c|c|c|}
\hline \multirow{2}{*}{ Biological characteristics } & \multicolumn{6}{|c|}{ Age of host Nezara viridula (hours) } & & \multirow{2}{*}{ Overall average } \\
\hline & $24 \mathrm{~h}$ & $48 \mathrm{~h}$ & $72 \mathrm{~h}$ & $96 \mathrm{~h}$ & $120 \mathrm{~h}$ & $144 \mathrm{~h}$ & & \\
\hline Parasitism (\%) & $37.78 \pm 6.19$ & $73.33 \pm 8.43$ & $67.69 \pm 10.15$ & $60.00 \pm 6.29$ & $48.00 \pm 12.00$ & $92.73 \pm 4.88$ & n.s. & $63.26 \pm 7.92$ \\
\hline Emergency (\%) & $100.00 \pm 0.00$ & $91.67 \pm 8.33$ & $98.18 \pm 1.82$ & $91.58 \pm 6.03$ & $100.00 \pm 0.00$ & $100.00 \pm 0.00$ & n.s. & $96.91 \pm 1.69$ \\
\hline Life cycle $^{1}$ (days) & $18.82 \pm 0.12$ & $18.87 \pm 0.11$ & $18.12 \pm 0.21$ & $18.62 \pm 0.12$ & $19.95 \pm 0.45$ & $18.50 \pm 0.23$ & n.s. & $18.81 \pm 0.25$ \\
\hline Progeny ${ }^{2}$ & $2.32 \pm 0.31$ & $1.43 \pm 0.17$ & $1.75 \pm 0.17$ & $1.75 \pm 0.15$ & $1.81 \pm 0.42$ & $1.65 \pm 0.11$ & n.s. & $1.79 \pm 0.12$ \\
\hline sex ratio ${ }^{3}$ & $1.00 \pm 0.00$ & $1.00 \pm 0.00$ & $1.00 \pm 0.00$ & $1.00 \pm 0.00$ & $1.00 \pm 0.00$ & $1.00 \pm 0.00$ & n.s. & $1.00 \pm 0.00$ \\
\hline Longevity $\bigcirc$ (days) & $13.05 \pm 1.34$ & $11.15 \pm 1.83$ & $16.90 \pm 1.55$ & $12.60 \pm 1.74$ & $14.05 \pm 2.58$ & $12.80 \pm 1.46$ & n.s. & $13.43 \pm 0.79$ \\
\hline
\end{tabular}

Note. $n . s .=$ not significant $(\mathrm{p}>0.05) ;{ }^{1}$ egg duration-adult; ${ }^{2}$ number of individuals per egg; ${ }^{3}{ }^{\circ}$ of females $/\left(\mathrm{n}^{\circ}\right.$ of males $+\mathrm{n}^{\circ}$ of females).

Similar to $O$. submetallicus, the evaluated ages of $N$. viridula eggs did not significantly affect the biological characteristics of Trissolcus sp. aff. urichi $(\mathrm{p}>0.05)$. The parasitism of Trissolcus sp. aff. urichi in eggs of $N$. viridula at up to six days old $(144 \mathrm{~h})$ was $87.57 \pm 1.93 \%$ and only seven individuals emerged in the entire experiment (24 to $144 \mathrm{~h}$ ) (Table 4).

The average life cycle length (egg-adult) of Trissolcus sp. aff. urichi was $14.50 \pm 0.29$ days, with a number of $1.00 \pm 0.00$ individuals emerged per $N$. viridula egg. The overall average for sex ratio was $0.54 \pm 0.21$, because female and male parasitoids emerged, with average longevities of $15.83 \pm 6.09$ and $18.33 \pm 5.55$ days, respectively (Table 4).

Table 4. Biological characteristics (mean $\pm \mathrm{SE}$ ) of Trissolcus sp. aff. urichi (Hymenoptera: Scelionidae) emerged from eggs of Nezara viridula (Hemiptera: Pentatomidae) at $24,48,72,96,120$, or 144 hours of age, at $25 \pm 2{ }^{\circ} \mathrm{C}$, $70 \pm 10 \%$ of $(\mathrm{RH})$ and 12 -hour photophase. Dourados, Mato Grosso do Sul, Brazil

\begin{tabular}{lllllllll}
\hline \multirow{2}{*}{ Biological characteristics } & \multicolumn{9}{c}{ Age of host Nezara viridula (hours) } & \multirow{2}{*}{ Overall average } \\
\cline { 2 - 7 } & $24 \mathrm{~h}$ & $48 \mathrm{~h}$ & $72 \mathrm{~h}$ & $96 \mathrm{~h}$ & $120 \mathrm{~h}$ & $144 \mathrm{~h}$ & \\
\hline Parasitism (\%) & $85.00 \pm 9.82$ & $80.00 \pm 9.61$ & $89.23 \pm 6.25$ & $86.67 \pm 8.82$ & $92.86 \pm 3.39$ & $91.67 \pm 5.20$ & n.s. & $87.57 \pm 1.93$ \\
Emergency (\%) & - & $40.00 \pm 0.00$ & $20.00 \pm 0.00$ & - & $20.00 \pm 0.00$ & $35.00 \pm 15.00$ & n.s. & $28.75 \pm 5.15$ \\
Life cycle $^{1}$ (days) & - & $15.00 \pm 0.00$ & $15.00 \pm 0.00$ & - & $14.00 \pm 0.00$ & $14.00 \pm 1.00$ & n.s. & $14.50 \pm 0.29$ \\
Progeny $^{2}$ & - & $1.00 \pm 0.00$ & $1.00 \pm 0.00$ & - & $1.00 \pm 0.00$ & $1.00 \pm 0.00$ & n.s. & $1.00 \pm 0.00$ \\
sex ratio $^{3}$ & - & $1.00 \pm 0.00$ & $0.00 \pm 0.00$ & - & $0.67 \pm 0.33$ & $0.50 \pm 0.50$ & n.s. & $0.54 \pm 0.21$ \\
Longevity & - & $9.50 \pm 1.50$ & - & - & $28.00 \pm 0.00$ & $10.00 \pm 0.00$ & n.s. & $15.83 \pm 6.09$ \\
Longevity o & - & - & $20.00 \pm 0.00$ & - & $8.00 \pm 0.00$ & $27.00 \pm 0.00$ & n.s. & $18.33 \pm 5.55$ \\
\hline
\end{tabular}

Note. $n$.s. $=$ not significant $(\mathrm{p}>0.05) ;{ }^{1}$ total egg duration-adult $;{ }^{2}$ number of individuals per egg; $;{ }^{3} n^{\circ}$ of females $/\left(n^{\circ}\right.$ of males $+n^{\circ}$ of females).

\section{Discussion}

In general, it was observed that the percentage of $O$. submetallicus parasitism increased according to the age of the females. This fact is easily explained because the representatives of the Encytidae family present synovigenic maturation, that is, the eggs are produced and, consequently, matured throughout their adult life and in general the females need a few days to start oviposition (Flanders, 1950; Papaj, 2000; Kapranas \& Tena, 2015). Similar to our study, Aung et al. (2012) and Tunca (2016) verified an increase in the reproductive efficiency of Encyrtidae parasitoids from their fifth day of life.

Unlike O. submetallicus, the female ages of the parasitoid Trissolcus sp. aff. urichi did not influence the percentage of parasitism, remaining constant during the six days, possibly due to the viability of spermatozoa, guaranteed by the female's spermatheca during her reproductive phase (Damiens et al., 2003; Pascini \& Martins, 2017). Regarding the age of the eggs of the host $N$. viridula, this factor was not significant for the percentage of parasitism, once females of $O$. submetallicus parasitized eggs up to 144 hours of age, as verified by Binazzi et al. (2013), where the parasitoid Ooencyrtus pityocampae (Mercet) (Hymenoptera Encyrtidae) parasitized eggs at up to seven 
days old (168 h), with no interference in their reproductive capacity. The host age did not generate any significant response in the parasitism of Trissolcus sp. aff. urichi, remaining above $80 \%$ at all ages of $N$. viridula eggs, however, some Scelionidae parasitoids prefer younger eggs for reproduction, because as the eggs age their embryonic content may change, compromising the quality of their nutritional status (Peñaflor et al., 2012; Da Wedge et al., 2017).

The percentage of emergence was not influenced by the ages of $O$. submetallicus, presenting a rate above $85 \%$, as observed by Lee (1979) in his study on O. submetallicus and N. viridula. Similar to the age of the parasitoid, the various ages of $N$. viridula eggs did not cause variations in emergence since $O$. submetallicus emerged in more than $90 \%$ of the eggs at all ages of the host, similarly to what was described by Catalán and Verdú (2005), through the emergence of the progeny of the parasitoid Encyrtidae in more than $80 \%$ of the parasitized eggs of N. viridula.

Despite the multiple ages of Trissolcus sp. aff. urichi and N. viridula eggs not interfering in the percentage of emergence, few adults emerged in these bioassays. Possibly, the host does not have characteristics considered nutritionally suitable for the perfect development of the progenies, or even, due to non-reproductive effects such as the abortion of the parasitoid's eggs performed by the host's own immune system (Strand \& Pech, 1995; Roversi, 2017; Abram et al., 2019). Botch and Delfosse (2018) also verified low percentage of the emergence of the parasitoid Trissolcus japonicus (Ashmead) (Hymenoptera: Scelionidae) in eggs of non-target Pentatomidae hosts, and the authors associated this factor to the absence of interaction and/or non-suitability of the parasitoid to the host.

Both the age of $O$. submetallicus females and the age of $N$. viridula eggs did not interfere in the life cycle length of this parasitoid or in the number of individuals per egg, discriminating that the parasitoid can develop normally regardless of the age of the progenitor or host, which is similar to what was observed by Power et al. (2020) who, when studying alternative hosts for the reproduction of Ooencyrtus mirus (Triapitsyn and Power) (Hymenoptera: Encyrtidae), noted that the development time of this parasitoid in N. viridula eggs was approximately 15 days, being a suitable host for the reproduction of this parasitoid Encyrtidae. In our study, there was the emergence of more than one individual per egg, possibly due to the low density of eggs provided by females of O. submetallicus, with more than one adult emerging from a single host (Böckmann et al., 2012; Tunca et al., 2017). However, superparasitism tends to to lead to intraspecific competition within the host, which limits the nutrition of the progeny and can compromise the development of these parasitoids (Tunca et al., 2017).

The ages of Trissolcus sp. aff. urichi and $N$. viridula eggs did not influence the life cycle, the number of individuals per egg, and the longevity of males and females of this parasitoid, however, these characteristics were compromised by the non-target host, possibly due to its limited nutritional resources, inadequate egg size or even by the barriers of its immune system, as already mentioned (Vinson, 1976; Strand \& Vinson, 1983; Abram et al., 2019). Other authors also report that T. urichi does not always develop in N. viridula eggs (Sujii et al., 2002), although its biological characteristics may undergo variations when subjected to other hosts of the Pentatomidae family (Laumann et al., 2008, 2010; Barakat et al., 2020).

The longevity of $O$. submetallicus progeny decreased as the age of the female increased, because as the parasitoid females age, there is a limitation of their nutritional resources that would be destined to the process of ovogenesis, resulting in the deficiency of proteins, carbohydrates, and lipids in their eggs (Giron \& Casas, 2003; Muller et al., 2017). Therefore, the reduction in the number of eggs resulting from the increase in the age of the female progenitor may affect the process of nutrition of the offspring, thereby decreasing their aptitude and longevity (Lansing, 1947; Kindsvater \& Otto, 2014; Plaistow et al., 2015; Muller et al., 2017). Unlike this, the age of the eggs of $N$. viridula did not have any effect on the longevity of $O$. submetallicus and it survived more than ten days, however, when compared to other host species and submitted to different diets, the longevity of the parasitoid may suffer several variations (Roversi et al., 2018).

Regardless of the age of $O$. submetallicus or $N$. viridula eggs, the sex ratio was characterized by the absolute presence of female individuals. The parasitoid $O$. submetallicus reproduces by thelytokous parthenogenesis, generating only female parasitoids at temperatures below $29.44{ }^{\circ} \mathrm{C}$, however, males can also be produced at particular temperature variations (Wilson \& Wooloo, 1952). This characteristic was also not influenced by the ages of Trissolcus sp. aff. urichi and neither by the different ages of the eggs of $N$. viridula, being characterized by the presence of male and female individuals, which is similar to what was observed by Queiroz et al. (2020b) through the emergence of individuals of both sexes of T. urichi in eggs of Pentatomidae hosts. From the results obtained and the discussion raised, this work provides grounds and opens the possibility for future studies about other stink bugs of the Pentatomidae complex, with the possibility of implementing new protocols for multiplication and for 
subsequent release of these species of parasitoids in a synchronized manner with the occurrence of stink bug populations in the field.

\section{Acknowledgements}

The authors are grateful for the support of the Laboratório de Controle Biológico de Insetos (LECOBIOL), the Universidade Federal da Grande Dourados, the Programa de Pós-Graduação em Entomologia e Conservação da Biodiversidade and CAPES (Coordenação de Aperfeiçoamento de Pessoal de Nível Superior), for granting the research scholarship. To CNPQ (Conselho Nacional de Desenvolvimento Científico e Tecnológico) (Processes $304055 / 2019-0 ; 437490 / 2018-1,140852 / 2017-4)$, for the financial support to carry out the research. The authors also thank the Fundação de Amparo à Pesquisa do Estado de São Paulo (FAPESP, grant number 2017/50334-3 and 2018/18965-6) and the Instituto Nacional de Ciência e Tecnologia de Hymenoptera Parasitoides (Proc. $65562 / 2014-0$ ), for the support to one of the authors (VAC).

\section{References}

Abram, P. K., Brodeur, J., Urbaneja, A., \& Tena, A. (2019). Nonreproductive effects of insect parasitoids on their hosts. Annual Review of Entomology, 64, 259-276. https://doi.org/10.1146/annurev-ento-011118-111753

Aung, K. S. D., Takasu, K., Ueno, T., \& Takagi, M. (2012). Effect of Host-Feeding on Reproduction in Ooencyrtus nezarae (Ishii). Jornal of the Faculty of Agriculture, 57, 115-120. https://doi.org/10.5109/22057

Barakat, M. C., Liljesthröm, G. G., \& Cingolani, M. F. (2020). Preimaginal developmental time of two egg parasitoids and their host searching efficiency. Biocontrol Science and Technology, 30, 559-568. https://doi.org/10.1080/09583157.2020.1745148

Binazzi, F., Benassai, D., Peverieri, G. S., \& Roversi, P. F. (2013). Effects of Leptoglossus occidentalis Heidemann (Heteroptera Coreidae) egg age on the indigenous parasitoid Ooencyrtus pityocampae Mercet (Hymenoptera Encyrtidae). Redia, 96, 79-84.

Böckmann, E. A., Tormos, J., Beitia, F., \& Fischer, K. (2012). Offspring production and self-superparasitism in the solitary ectoparasitoid Spalangia cameroni (Hymenoptera: Pteromalidae) in relation to host abundance. Bulletin of Entomological Research, 102, 131-137. https://doi.org/10.1017/S0007485311000447

Botch, P. S., \& Delfosse, E. S. (2018). Host-acceptance behavior of Trissolcus japonicus (Hymenoptera: Scelionidae) reared on the invasive Halyomorpha halys (Heteroptera: Pentatomidae) and nontarget species. Environmental Entomology, 47, 403-411. https://doi.org/10.1093/ee/nvy014

Catalán, J., \& Verdú, M. J. (2005). Evaluación de dos parasitoides de huevos de Nezara viridula. Boletín de sanidad vegetal. Plagas, 31, 187-198.

Chiesa, A. C. M., Sismeiro, M. N. S., Pasini, A., \& Roggia, S. (2016) Tratamento de sementes para manejo do percevejo-barriga-verde na cultura de soja e milho em sucessão. Pesquisa Agropecuária Brasileira, 51, 30-308. https://doi.org/10.1590/S0100-204X2016000400002

Cingolani, M. F., Greco, N. M., \& Liljesthröm, G. G. (2014). Effect of Telenomus podisi, Trissolcus urichi, and Trissolcus basalis (Hymenoptera: Platygastridae) age on attack of Piezodorus guildinii (Hemiptera: Pentatomidae) Eggs. Environmental Entomology, 43, 377-383. https://doi.org/10.1603/EN13250

Corrêa-ferreira, B. S., \& Moscardi, F. (1996). Biological control of soybean stink bugs by inoculative releases of Trissolcus basalis. Entomologia Experimentalis et Applicata, 79, 1-7. https://doi.org/10.1111/j.1570-7458. 1996.tb00802.x

Crouzel, I. S., \& Saini, E. D. (1981). Importacion de Trissolcus basalis (Wollaston) (Hym. Scelionidae) en la Argentina para el control biologico de Nezara viridula (L.) (Hem. Pentatomidae). Revista de la Sociedad Entomológica Argentina, 4, 257-260.

Damiens, D., Bressac, C., \& Chevrier, C. (2003). The effect of age on sperm stock and egg laying in the parasitoid wasp, Dinarmus basalis. Journal of Insect Science, 3, 22. https://doi.org/10.1093/jis/3.1.22

Flanders, S. E. (1950). Regulation of Ovulation and Egg Disposal in the Parasitic Hymenoptera. The Canadian Entomologist, 82, 134-140. https://doi.org/10.4039/Ent82134-6

Giron, D., \& Casas, J. (2003). Mothers reduce egg provisioning with age. Ecology Letters, 6, 273-277. https://doi.org/10.1046/j.1461-0248.2003.00429.x

Golin, V., Loiácono, M. S., Margaría, C. B., \& Aquino, D. A. (2011). Natural incidence of egg parasitoids of Edessa meditabunda (F.) (Hemiptera: Pentatomidae) on Crotalaria spectabilis in Campo Novo do Parecis, 
MT, Brazil. Neotropical Entomology, 40, 617-618. https://doi.org/10.1590/S1519-566X2011000500015

Hill, J. G., Albarracin, E. L., Araoz, M. V. C., \& Virla, E. G. (2019). Effects of host species and host age on biological parameters of Anagrus virlai (Hymenoptera: Mymaridae), an egg parasitoid of Dalbulus maidis (Hemiptera: Cicadellidae) and Peregrinus maidis (Hemiptera: Delphacidae). Biological Control, 131, 74-80. https://doi.org/10.1016/j.biocontrol.2018.12.002

Johnson, N. F. (1987). Systematics of New World Trissolcus, a genus of pentatomid egg-parasites (Hymenoptera: Scelionidae): Neotropical species of the flavipes group. Journal of Natural History, 21, 285-304. https://doi.org/10.1080/00222938700771021

Kapranas, A., \& Tena, A. (2015). Encyrtid parasitoids of soft scale insects: Biology, behavior, and their use in biological control. Annual Review of Entomology, 60, 195-211. https://doi.org/10.1146/annurev-ento010814-021053

Kindsvater, H. K., \& Otto, S. P. (2014). The evolution of offspring size across life-history stages. American Naturalist, 184, 543-555. https://doi.org/10.1086/678248

Lansing, A. I. (1947). A transmissible, cumulative, and reversible factor in aging. Journal of Gerontology, 2, 228-239. https://doi.org/10.1093/geronj/2.3.228

Laumann, R. A., Moraes, M. C. B., Pareja, M., Alarcao, G. C., Botelho, A. C., Maia, A. H. N., ... Borges, M. (2008). Comparative biology and functional response of Trissolcus spp. (Hymenoptera: Scelionidae) and implications for stink bugs (Hemiptera: Pentatomidae) biological control. Biological Control, 44, 32-41. https://doi.org/10.1016/j.biocontrol.2007.10.003

Laumann, R. A., Moraes, M. C. B., Silva, J. P. D., Vieira, A. M. C., Silveira, S. D., \& Borges, M. (2010). Egg parasitoid wasps as natural enemies of the neotropical stink bug Dichelops melacanthus. Pesquisa Agropecuária Brasileira, 45, 442-449. https://doi.org/10.1590/S0100-204X2010000500002

Lee, S. C. (1979). Evaluation of Ooencyrtus submetallicus (Howard) and Trissolcus basalis (Wollaston) as egg parasites of Nezara viridula (Linnaeus). Korean Journal of Plant Protection, 18, 199-200.

Maciel, A. A., de Lemos, R. N., Souza, J. R. D., Costa, V. A., Barrigossi, J. A., \& Chagas, E. F. D. (2007). Parasitismo de ovos de Tibraca limbativentris Stal (Hemiptera: Pentatomidae) na cultura do arroz no Maranhão. Neotropical Entomology, 36, 616-618. https://doi.org/10.1590/S1519-566X2007000400023

Martel, G., Augé, M., Talamas, E., Roche, M., Smith, L., \& Sforza, R. F. H. (2019). First laboratory evaluation of Gryon gonikopalense (Hymenoptera: Scelionidae), as potential biological control agent of Bagrada hilaris (Hemiptera: Pentatomidae). Biological Control, 135, 48-56. https://doi.org/10.1016/j.biocontrol.2019.04.014

Muller, D., Giron, D., Desouhant, E., Rey, B., Casas, J., Lefrique, N., \& Visser, B. (2017). Maternal age affects offspring nutrient dynamics. Journal of Insect Physiology, 101, 123-131. https://doi.org/10.1016/j.jinsphys. 2017.07.011

Noyes, J. S. (2000). Encyrtidae of Costa Rica (Hymenoptera: Chalcidoidea), 3. Subfamily Encyrtinae: Encyrtini, Echthroplexiellini, Discodini, Oobiini and Ixodiphagini, parasitoids associated with bugs (Hemiptera), insect eggs (Hemiptera, Lepidoptera, Coleoptera, Neuroptera) and ticks (Acari). Memoirs of the American Entomological Institute, 84, 1-848.

Panizzi, A. R., \& Slansky Jr, F. (1985). Review of phytophagous pentatomids (Hemiptera: Pentatomidae) associated with soybean in the Americas. Florida Entomologist, 68, 184-214. https://doi.org/10.2307/ 3494344

Papaj, D. R. (2000). Ovarian dynamics and host use. Annual Review of Entomology, 45, 423-448. https://doi.org/10.1146/annurev.ento.45.1.423

Parra, J. R. P. (2014). Biological control in Brazil: an overview. Scientia Agricola, 71, 420-429. https://doi.org/ 10.1590/0103-9016-2014-0167

Parra, J. R. P., \& Coelho, A. (2019). Applied Biological Control in Brazil: From Laboratory Assays to Field Application. Journal of Insect Science, 19, 1-6. https://doi.org/10.1093/jisesa/iey112

Parra, J. R. P., \& Zucchi, R. A. (2004). Trichogramma in Brazil: feasibility of use after twenty years of research. Neotropical Entomology, 33, 271-281. https://doi.org/10.1590/S1519-566X2004000300001

Parra, J. R. P., Botelho, P. S. M., Correa-Ferreira, B. S., \& Bento, J. M. S. (2002). Controle biológico no Brasil: Parasitóides e predadores. Manole, São Paulo, SP, Brasil. 
Pascini, T. V., \& Martins, G. F. (2017). The insect spermatheca: an overview. Zoology, 121, 56-71. https://doi.org/10.1016/j.zool.2016.12.001

Paz-Neto, A. D. A., Querino, R. B., \& Margaría, C. B. (2015). Egg Parasitoids of Stink Bugs (Hemiptera: Coreidae and Pentatomidae) on Soybean and Cowpea in Brazil. Florida Entomologist, 98, 929-932. https://doi.org/ $10.1653 / 024.098 .0318$

Peñaflor, M. F. G. V., Sarmento, M. M. M., Silva, C. S. B., Werneburg, A. G., \& Bento, J. M. S. (2012). Effect of host egg age on preference, development and arrestment of Telenomus remus (Hymenoptera: Scelionidae). European Journal of Entomology, 109, 15-20. https://doi.org/10.14411/eje.2012.003

Plaistow, S. J., Shirley, C., Collin, H., Cornell, S. J., \& Harney, E. D. (2015). Offspring provisioning explains clone-specific maternal age effects on life history and life span in the water flea, Daphnia pulex. The American Naturalist, 186, 376-389. https://doi.org/10.5061/dryad.3k8c0

Power, N., Ganjisaffar, F., \& Perring, T. M. (2020). Evaluation of the physiological host range for the parasitoid Ooencyrtus mirus, a potential biocontrol agent of Bagrada hilaris. Insects, 11, 1-16. https://doi.org/10.3390/ insects 11070432

Queiroz, A. P. D., Costa, C. O., Favetti, B. M., Silva, G. V., \& Bueno, A. D. F. (2020a). Effects of parasitoid and host age on the parasitism of Trichogramma pretiosum on eggs of Anticarsia gemmatalis. Revista Brasileira de Entomologia, 64. https://doi.org/10.1590/1806-9665-RBENT-2019-105

Queiroz, A. P., Bueno, A. F., Panizzi, A. R., Favetti, B. M., Grande, M. L. M., \& Luski, P. G. G. (2020b). Biological characteristics of Trissolcus urichi (Crawford) (Hymenoptera: Scelionidae) on Euschistus heros (Fabricius) and Dichelops melacanthus (Dallas) (Hemiptera: Pentatomidae) Eggs. Scientific Reports, 10, 1-7. https://doi.org/10.1038/s41598-020-69406-z

Queiroz, A. P., Favetti, B. M., Hayashida, R., Grande, M. L. M., Neiva, M. M., Panizzi, A. R., \& Bueno, A. D. F. (2019). Effect of the ages of parasitoid and host eggs on Telenomus podisi (Hymenoptera: Platygastridae) parasitism. Neotropical Entomology, 48, 974-982. https://doi.org/10.1007/s13744-019-00724-2

Queiroz, A. P., Taguti, E. A., Bueno, A. F., Grande, M. L. M., \& Costa, C. O. (2018). Host preferences of Telenomus podisi (Hymenoptera: Scelionidae): Parasitism on eggs of Dichelops melacanthus, Euschistus heros, and Podisus nigrispinus (Hemiptera: Pentatomidae). Neotropical Entomology, 47, 543-552. https://doi.org/10.1007/s13744-017-0564-5

Riffel, C. T., Prando, H. F., \& Boff, M. I. C. (2010). Primeiro relato de ocorrência de Telenomus podisi (Ashmead) e Trissolcus urichi (Crawford) (Hymenoptera: Scelionidae) como parasitóides de ovos do percevejo-do-colmo-do-arroz, Tibraca limbativentris (Stål) (Hemiptera: Pentatomidae), em Santa Catarina. Neotropical Entomology, 39, 447-448. https://doi.org/10.1590/S1519-566X2010000300021

Roversi, P. F., Binazzi, F., Marianelli, L., Costi, E., Maistrello, L., \& Peverieri, G. S. (2017). Searching for native egg-parasitoids of the invasive alien species Halyomorpha halys Stål (Heteroptera Pentatomidae) in Southern Europe. Redia, 99, 63-70. https://doi.org/10.19263/REDIA-99.16.01

Roversi, P. F., Maltese, M., Simoni, S., Cascone, P., Binazzi, F., Strangi, A., Peverieri, G. S., \& Guerrieri, E. (2018). Graphosoma lineatum (Hemiptera: Pentatomidae): A suitable host for mass rearing Ooencyrtus telenomicida (Hymenoptera: Encyrtidae). International Journal of Pest Management, 64, 294-302. https://doi.org/ 10.1080/09670874.2017.1403059

Scaccini, D., Falagiarda, M., Tortorici, F., Martinez-Sañudo, I., Tirello, P., Reyes-Domínguez, Y., ... Pozzebon, A. (2020). An insight into the role of Trissolcus mitsukurii as biological control agent of Halyomorpha halys in Northeastern Italy. Insects, 11, 306. https://doi.org/10.3390/insects11050306

Silva, C. C., Laumann, R. A., Blassioli, M. C., Pareja, M., \& Borges, M. (2008). Euschistus heros mass rearing technique for the multiplication of Telenomus podisi. Pesquisa Agropecuária Brasileira, 43, 575-580. https://doi.org/10.1590/S0100-204X2008000500004

Siqueira, J. R., Bueno, R. C. O. F., Bueno, A. F., \& Vieira, S. S. (2012). Preferência hospedeira do parasitoide de ovos Trichogramma pretiosum. Ciência Rural, 42, 1-5. https://doi.org/10.1590/S0103-84782011005000156

Soares, P. L., Cordeiro, E. M. G., Santos, F. N. S., Omoto, C., \& Correa, A. S. (2018). The reunion of two lineages of the Neotropical brown stink bug on soybean lands in the heart of Brazil. Scientifics Reports, 8, 2496. https://doi.org/10.1038/s41598-018-20187-6

Sosa-Gómez, D. R., \& Silva, J. J. (2010) Neotropical brown stink bug (Euschistus heros) resistance to 
methamidophos in Paraná, Brazil. Pesquisa Agropecuária Brasileira, 4, 767-769. https://doi.org/10.1590/ S0100-204X2010000700019

Sosa-Gómez, D. R., Corso, I. C., \& Morales, L. (2001) Insecticide resistance to endosulfan, monocrotophos and metamidophos in the neotropical brown stink bug, Euschistus heros (F.). Neotropical Entomology, 30, 317-320. https://doi.org/10.1590/S1519-566X2001000200017

Sousa, K. K. A., Silva, N. N. P., Querino, R. B., Silva, P. H. S., \& Grazia, J. (2019). Diversity, seasonality, and egg parasitism of hemipteran (Coreidae and Pentatomidae) from a cowpea crop in northeastern Brazil. Florida Entomologist, 102, 29-35. https://doi.org/10.1653/024.102.0105

Stahl, J. M., Babendreier, D., \& Haye, T. (2019). Life history of Anastatus bifasciatus, a potential biological control agent of the brown marmorated stink bug in Europe. Biological Control, 129, 178-186. https://doi.org/10.1016/j.biocontrol.2018.10.016

Strand, M. R., \& Vinson, S. B. (1983). Physical factors affecting host recognition in the egg parasitoid Telenomus heliothidis. Environmental Entomology, 12, 1114-1119. https://doi.org/10.1093/ee/12.4.1114

Strand, M., \& Pech, L. (1995). Immunological basis for compatibility in parasitoid-host relationships. Annual Review of Entomology, 40, 31-56. https://doi.org/10.1146/annurev.en.40.010195.000335

Sujii, E. R., Costa, M. L. M., Pires, C. S. S., Colazza, S., \& Borges, M. (2002). Inter and intra-guild interactions in egg parasitoid species of the soybean stink bug complex. Pesquisa Agropecuária Brasileira, 37, 1541-1549. https://doi.org/10.1590/S0100-204X2002001100004

Thancharoen, A., Lankaew, S., Moonjuntha, P., Wongphanuwat, T., Sangtongpraow, B., Ngoenklan, R., ... Wyckhuy, K. A. G. (2018). Efective biological control of an invasive mealybug pest enhances root yield in cassava. Journal of Pest Science, 91, 1199-1211. https://doi.org/10.1007/s10340-018-1012-y

Tunca, H., Colombel, E. A., Ben Soussan, T., Buradino, M., Galio, F., \& Tabone, E. (2016). Optimal biological parameters for rearing Ooencyrtus pityocampae on the new laboratory host Philosamia ricini. Journal of Applied Entomology, 140, 527-535. https://doi.org/10.1111/jen.12282

Tunca, H., Colombel, E. A., Venard, M., \& Tabone, E. (2017). Incidence of superparasitism in the egg parasitoid, Ooencyrtus kuvanae Howard (Hymenoptera: Encyrtidae). Biocontrol Science and Technology, 27, 796-808. https://doi.org/10.1080/09583157.2017.1342765

Turchen, L. M., Golin, V., Butnariu, A. R., Guedes, R. N. C., \& Pereira, M. J. B. (2016). Lethal and sublethal effects of insecticides on the egg parasitoid Telenomus podisi (Hymenoptera: Platygastridae). Journal of Economic Entomology, 109, 84-92. https://doi.org/10.1093/jee/tov273

Van Lenteren, J. C., Bolckmans, K., Köhl, J., Ravensberg, W. J., \& Urbaneja, A. (2018). Biological control using invertebrates and microorganisms: plenty of new opportunities. BioControl, 63, 39-59. https://doi.org/ $10.1007 / \mathrm{s} 10526-017-9801-4$

Vinson, S. B. (1976). Host Selection by Insect Parasitoids. Annual Review of Entomology, 21, $109-133$. https://doi.org/10.1146/annurev.en.21.010176.000545

Wilson, F., \& Wooloo, L. T. (1952). Temperature determination of sex in a parthenogenetic parasite, Ooencyrtus submetallicus (Howard) (Hymenoptera: Encyrtidae). Australian Journal of Zoology, 8, 153-169. https://doi.org/10.1071/ZO9600153

Zanuncio, J. C., Oliveira, H. N., Torres, J. B., \& Pratissoli, D. (2000). Egg parasitoids of Podisus sculptus distant (Heteroptera: Pentatomidae) in an Eucalyptus plantation in the Brazilian Amazonian Region. Revista de Biologia Tropical, 48, 989-992.

Zerbino, M. S., \& Panizzi, A. R. (2019). The underestimated role of pest pentatomid parasitoids in Southern South America. Arthropod-Plant Interactions, 13, 703-718. https://doi.org/10.1007/s11829-019-09703-1

\section{Copyrights}

Copyright for this article is retained by the author(s), with first publication rights granted to the journal.

This is an open-access article distributed under the terms and conditions of the Creative Commons Attribution license (http://creativecommons.org/licenses/by/4.0/). 